\title{
Does Foreign Direct Investment Lead to Economic Growth? Evidences from Asian Developing Countries
}

\author{
Najaf Ali $^{1} \&$ Ye Mingque ${ }^{1}$ \\ ${ }^{1}$ School of Economics, Shanghai University, Shanghai, China \\ Correspondence: Najaf Ali, School of Economics, Shanghai University, 99 Shangda Road (200444) Shanghai, \\ China. E-mail: najaf126@t.shu.edu.cn
}

Received: January 9, 2018

Accepted: January 29, 2018

Online Published: February 5, 2018

doi:10.5539/ijef.v10n3p109

URL: https://doi.org/10.5539/ijef.v10n3p109

\begin{abstract}
The study about the interrelationship between FDI and economic growth in the host country is one of the hottest discussions. Some of the studies have evidence and consider FDI as the growth driver and some others don't. This study attempted to scrutinize the causal association of FDI with GDP in Indonesia, India, Malaysia and Bangladesh for the years of 1990 to 2014. Cointegration test has been applied in this study which shows that there is a long-term interrelationship within FDI and economic growth and then applied the Granger causality (GC) test which is based on the VECM. The short run results show that there are no evidence of causality direction from FDI to GDP and vice versa, whereas the long run results show that there is a positive impact of FDI and other variables to the GDP but not significant, and from GDP and other variables to FDI there is a negative interrelationship but significant. The results show the ambiguous interrelationship between FDI and economic growth.
\end{abstract}

Keywords: FDI, developing countries, economic growth, VECM

\section{Introduction}

Foreign Direct Investment (FDI) has gained more importance after world war second. Before that FDI was seen with a lot of suspicion by many emerging countries but now the quandary has removed and it is considered as a catalyst for economic development and an important source of transferring technology from developed to developing nations. Actually this is a foreign country investment, which is referred by FDI, where the investor keeps control over the investment. This is long-term investment which can't be effortlessly liquidated. In ancient time, FDI was considered a factor of supremacy by developed countries on developing countries but now is taken as a major source of transferring technology and innovation. Indeed now Foreign Direct Investment is slightly having more and more important by both developed and developing countries. FDI is gradually fueling economic growth by new ways of financing. Inward FDI is the main source of increasing and boosting the supply of funds for capital formation in the host country. All this is done through a chain which is called the production chain where the foreign sponsors buy inputs of local manufacturers and sell the raw material to local enterprises. Moreover developing countries can increase their foreign exchange earnings and also increase their export capacity. FDI inflow also encourages in job opportunities, in transferring technology and in economic growth of the host country.

FDI inflow is one of the key elements which can play an important role in the enhancement and boosting the source of fund for inland investment in the host country. All this can be done by the manufacture chain; like a foreign firm buy an input manufactured by the host country's firm and in return sell an input to the host country's firm. Moreover inflow of FDI plays a vital role in the enhancement of host country's export volume and the host country can increase its foreign exchange earnings. Furthermore FDI creates the opportunities for new jobs, enhancement of transferring technology, and increase general economic growth of the host country. Günther (2002); Wang and Blomström (1992) categorize that there are four main channels of transferring technology from foreign firm to host firm which are, imitation the second one is competition the third one is skills and the last one is linkages. The first one the imitation is also called the learning by watching. It happens when the local firm learns the technology and improves its knowledge by watching the technology used by the foreign firm. The existence of the foreign firm, this situation creates the atmosphere of competition, the other thing is that this that the local country's labor lean many things and technology by the foreign firm and it enhance their skills and the 
last channel is that by foreign firms it enhance the linkages from local to international market (De Mello \& R, 1999; Jr., 1997; Wang \& Blomström, 1992). Spillover effects are also caused by the FDI through these spillovers transferring of knowledge can be occurred. These spillover effects are occurred by the motility of skillful workers from foreign firm to local firms (Fosfuri, Motta, \& Rønde, 2001; Glass \& Saggi, 2002; Kaufmann, 1997). Usually the spillover effects occurs from linkages and these spillover have different kinds like when the foreign firm have a spillover on the host country's firm in the same manufacturing plant it is called horizontal spillover and if this spillover occurs in the upstream and downstream manufacturing plant then it is called vertical spillovers (Borensztein \& De Gregorio, 1998).

Most of the past quantitative studies research on either trade and FDI interrelationship and its effect on economic growth Balasubramanyam, Salisu, and Sapsford, (1996); Kalai and Zghidi (2017); Pahlavani, Wilson, and Worthingt (2005) or deal with the interrelationship within FDI and economic growth (Lipsey, 2000). The conclusion of all these studies was that inward FDI and trade stimulate economic growth, but all were unable to deliver a definite proof on the interrelation and the conclusive direction particularly in developing countries. The effect of FDI and trade on economic growth is varied in every country and different from time to time. In some countries, FDI has a positive effect on growth (Alshehry, 2015; Belloumi, 2014; Borensztein \& De Gregorio, 1998; Umoh, Jacob, \& Chuku, 2012). In some countries, FDI affect growth negatively (Ayanwale, 2007; Carkovic \& Levine, 2002; Lian \& Ma, 2013; Xu, 2000).

All the above discussion shows that there are many studies in the past which have discussed and scrutinized all those issues and interrelationships within FDI and economic growth and have established their outcomes in the perspective of numerous emerging and developed economies. After going through the literature this study finds and reveals a gap in the perspective of the causal interrelation within the FDI and economic growth in the Asian developing countries. This study fills the gap through examining the causal linkages within FDI and economic growth in the perspective of Asian emerging countries by using the VECM approach and Granger Causality technique.

\section{Review of Literature}

In case of developing countries it is believed that FDI is the source of external capital and lead to economic growth. At firm level, it is believed that technology spillover is the source of augmenting productivity of a firm which is proved by numerous studies (Zhou, $\mathrm{Li}, \& \mathrm{Tse}, 2002$ ). On the other hand at macro level FDI has a positive contribution and lead to high economic growth Zhao and Zhang (2010), and to a higher level of positive output externalities (Wang, 2010). As we have explained in the introduction in new classical model FDI encourages growth by enhancing the capacity of total investment and on the other hand in the case of endogenous growth theory FDI encourages growth via transferring technology and generating knowledge spillover via foreign to targeted host country, which means the host country receive knowledge skills, inputs, knowledge about technology from developed countries (Balasubramanyam et al., 1996; Jr., 1997). Moreover FDI creates sources of jobs (Lipsey, Sjöholm, \& Sun, 2013; Waldkirch, Nunnenkamp, \& Bremont, 2009). Some other researchers inspect that FDI also has causal effect on exports and also on the transferring of technology and improvement of external part of market to enhance up gradation (Brooks, Roland-Holst, \& Zhai, 2008; Vogiatzoglou \& Nguyen, 2016; Zhang \& Song, 2000).

After going through the positive aspects of FDI, there are some negative aspects of FDI on the host country's economy. If firms are not export based then FDI might be the cause of more pressure on host country's firms. Moreover FDI might be the cause of reduction in natural resources and also the cause of pollution (Acharyya, 2009), FDI causes the enhancement of host country's wages (Figlio, 2000; Tomohara \& Takii, 2011). The enhancement of wages later affects the prices of the locally made inputs. Moreover FDI produce inequality in the host country it focusses on the technology and industry and ignores the importance of agriculture and then decreases the share of agriculture input in the GDP of the host country (Basu \& Guariglia, 2007). Even though there are some negative aspects of FDI exist in the host countries but the importance of FDI is still powerfully believed that still FDI has a positive effect on most of the developing economies.

Ghirmay, Grabowski, and Sharma (2001) inspects the interrelationship within exports and GDP in 19 developing economies, he uses the multivariate causality analysis established on the bases of ECM. Their results show that only in twelve out of nineteen developing countries there is a long run interrelationship within proposed variables. Moreover they found that in fifteen out of the nineteen countries export extension lead to the growth. Asheghian (2004) examine the causal link of FDI with growth in USA, He utilized the Grangerer Causality based methodology. The results of his study reveal the causality running from FDI to growth which shows that FDI also has importance in the USA. Mencinger (2003) investigated the causal interrelation within FDI and 
growth by using the panel data of 8 countries for the period of 1994 to 2001, his results show that unilateral interrelation and causality is running from FDI to growth. Bhatt (2014) investigates the causal interrelationship within exports, FDI and GDP in Asian countries. By using the VAR model the study shows that there is a long run interrelationship within proposed variables. Moreover the study shows that there is unilateral interrelationship within FDI and GDP running from FDI to GDP. Tan and Tang (2016) investigate the linkages within the FDI, trade and growth in Asian countries. Found that long run causal interrelationship within domestic investment and FDI, moreover they found both domestic investment and FDI as growth increasing. Pegkas (2015) estimates the causal interrelationship within FDI and growth for the period of 2002 to 2012. The study employed the panel data analysis by using the FMOLS and DOLS methods found that there long run interrelationship within FDI and growth. Fedderke and Romm (2006) examine the interrelationship within FDI and growth for the period of 1960 to 2003 in South Africa and found that FDI and GDP are cointegrated with each other in the long run and the direction of causality is from FDI to GDP. The same results are found in the study of (Frimpong, Joseph \& Oteng-Abayie, 2006). Similar results are found in the study of China. They found that FDI has a causal impact on the economy of China, moreover FDI is encouraging domestic investment in China (Tang, Selvanathan, \& Selvanathan, 2008) . Reichert, Nair, and Weinhold (2001) investigate the causal interrelationship within developing nations over the duration of 1980 to 1985 and found the causal interrelationship within FDI and domestic investment and growth. Rahman (2007) inspect the FDI and exports effect on the real GDP in Pakistan, India, Sri Lanka and Bangladesh over the time span of 1976 to 2006. He utilizes the ARDL technique and confirmed that the interrelationship exists in three countries. His results show that the in the case of Bangladesh there is export effect on GDP is more effective than FDI. The similar results are found in the case of India.

Apart from the positive empirical studies there are numerous studies which are unable to identify the causal link between the proposed variables and GDP. Basu, Chakraborty, and Reagle (2003) reveals the results of the 23 developing economies by using panel data analysis. They found the long run cointegration interrelationship within FDI and GDP moreover there is bilateral causality is found within GDP and FDI in open economies and on the other hand for closed economies there is causality running from GDP to FDI. Herzer, Klasen, \& Nowak-Lehmann (2008) reinspect the FLGH in 28 developing economy, they use the techniques of cointegration country by country. Their results show that there is no influence of FDI on growth in the short run as well as in the long run even not in a single country there is not a unidirectional interrelationship within FDI to GDP. Duasa, 2007; Kakar and Khilji (2011) inspected the casual interrelationship within FDI and economic growth in Malaysia and Pakistan, their results found nothing strong indications of causal interrelationship within these two variables. There is zero evidence of FDI cause growth or the growth cause FDI. Ludosean (2012) investigates the effect of FDI on growth for the period of 1991 to 2009 in Romania. His results found nothing clarified effect of FDI on growth. He uses of VAR model to categorize the interrelationship within the variables but found nothing. Mutafoglu (2012) investigates the interrelationship within the FDI, CO2 and economic improvement in Turkey over the time span of 1987 to 2009. Their results of cointegration test reveal that the long run interrelationship amongst the proposed variables and moreover they found the causal interrelationship within the variables but they found nothin the FLGH evidence. The same results are noted in the study of Akinlo (2004) inspects the FDI effect of growth of Nigeria over the period of 1970-2001. His results show that there is no significant results are found in both private capital and foreign capital. Other studies are also having same results like (Hsiao \& Hsiao, 2006; Kholdy, 1995).

Sothan (2017) consider FDI as the driver of growth, by using the data from the period of 1980 to 2014 in Cambodia. He employed the Granger causality test which has been established on the bases of Vector Error Correction Model (VECM), his results show that Cambodia's economy depends upon the causal impact of FDI on its growth causality is running from FDI to GDP. Chakraborty and Basu (2002) used the data from the period of 1974 to 1996 in India, explore the bilateral connection within the FDI and growth using the structural cointegration model, they use this model with VECM, in results the VECM shows that there are no causal link FDI to GDP of India. Moudatsou and Kyrkilis (2011) studied and explored the link within FDI and growth, they used the panel data analysis in EU and Asian countries for the period of 1970 to 2003. They used the VECM methodology and found that GDP causing FDI and on the other hand in Asia there is a unilateral causality within FDI and growth. Srinivasan, Kalaivani, and Ibrahim (2011) used the Johansen cointegration to analyze the interrelation within FDI and growth for SAARC countries for the period of 1970 to 2007. They employed the VECM to inspect the causal link within FDI and growth, the outcomes reveal the bilateral link in all countries except India, in India there unilateral link within FDI and growth. Belloumi (2014) examine the interrelationship within trade, FDI and economic growth in Tunisia over the duration of 1970 to 2008 . He utilizes the ARDL of bounds testing analysis and Granger causality which is built on the VECM. His results reveal that in the long run 
variables are bound together, besides the results of Granger causality are not significant, there are not evidences of significance of the direction of causality from FDI to growth, or vise versa short run, results also show that there are not any evidence that FDI generates positive spillover in the case of Tunisia.

After going through the literature of the conclusion is that the causality results on FDI and economic growth are still diverse and unconvincing. Most of the studies show their results of unilateral causality some other shows their results of bilateral and some of the studies show their results of ambiguous. Every study explained their results and the reason behind the diversification. All these results are due to the different estimation techniques to measure the FDI and growth. For instance some of the studies used the data of stock of FDI, some other used the data of inflow and some used the data percentage of GDP.

\section{Data and Estimation Strategy}

The purpose of our study is to scrutinize the causal link within FDI and GDP and other proposed variables of this study. We utilized panel data for the sample of four Asian low income countries over the duration of 1990 to 2014. The countries in our study are Bangladesh, Indonesia, India and Malaysia. The data have been acquired from the World Development Indicators WDI (2017) which is published by World Bank. The series of all suitable variables for this study consists of GDP (as the proxy of economic growth) is the dependent variable in this study and the independent variables, FDI, Gross Capital Formation (GCF), Government Consumption (GC), Trade Openness (TO) and Labor Force (L) have been included in this study. The general form the empirical model describes the interrelationship between economic growth, foreign direct investment and other variables:

$$
G D P_{t}=f\left(F D I_{t}, G C F_{t}, G C_{t}, T O_{t}, L_{t}\right)
$$

We have converted all the proposed variables into natural log to make the Eq: 1 examinable. The examinable form of Eq: 1 is demonstrated as follows:

$$
\ln G D P_{t}=\beta_{1}+\beta_{2} \ln F D I_{t}+\beta_{3} \ln G C F_{t}+\beta_{4} \ln G C_{t}+\beta_{5} \ln T O_{t}+\beta_{6} \ln L_{t}+\mu_{t}
$$

In this study, we are going to apply Johansen Cointegration test Johansen (1988) and Granger causality test established on the base of Vector Error Correction Model (VECM) to scrutinize the interrelationship within the GDP and FDI in Asian developing countries. But before going to all of these estimation the first step is that all the variables in the series must be verified the stationarity because it is observed that many variables are no-stationary. Before proceeding for the Cointegration test, the econometric methodology says all the suggested variables in the model must be integrated in order I(1). Fowowe (2011) described that after testing the unit root there are two ways of testing the causality (i) the first condition is that when the variables are integrated in order I(1) and Cointegrated then the VECM is the best choice to be used, see also (Emirmahmutoglu \& Kose, 2011; Fowowe, 2011; Moudatsou \& Kyrkilis, 2011; Zhang, 2001) the (ii) way is that if the proposed variables are not integrated in the same order then the causality should be proceed by the VAR approach, see also (Fowowe, 2011; Toda \& Phillips, 1993). But before going to the empirical analysis of a detailed summary of the proposed variables in Table 1. have been shown, which describe the mean, median and standard deviation of all variables in detail.

Table 1. Descriptive statistics

\begin{tabular}{lcccccc}
\hline & LNGDP & LNFDI & LNGC & LNGCF & LNL & LNTO \\
\hline Mean & 25.99787 & 21.28974 & 2.156699 & 3.254500 & 4.165648 & 4.019847 \\
Median & 25.88735 & 21.88826 & 2.269923 & 3.227145 & 4.157171 & 3.904730 \\
Maximum & 28.34517 & 24.49387 & 2.627718 & 3.774740 & 4.328098 & 5.395477 \\
Minimum & 24.15588 & 14.14513 & 1.399519 & 2.800853 & 3.990834 & 2.723859 \\
Std. Dev. & 1.093691 & 2.243901 & 0.370338 & 0.209478 & 0.084217 & 0.767825 \\
Skewness & 0.303574 & -1.250390 & -0.577838 & 0.340353 & 0.010632 & 0.440932 \\
Kurtosis & 2.254196 & 4.463787 & 1.853454 & 2.868344 & 2.079172 & 2.060313 \\
Jarque-Bera & 3.853549 & 34.98572 & 11.04232 & 2.002888 & 3.534905 & 6.919568 \\
Probability & 0.145617 & 0.000000 & 0.004001 & 0.367349 & 0.170768 & 0.031437 \\
Sum & 2599.787 & 2128.974 & 215.6699 & 325.4500 & 416.5648 & 401.9847 \\
Sum Sq. Dev. & 118.4198 & 498.4741 & 13.57790 & 4.344238 & 0.702162 & 58.36598 \\
Observations & 100 & 100 & 100 & 100 & 100 & 100 \\
\hline
\end{tabular}

\subsection{Panel Unit Root Test}

The econometric methodology says that all the variables included in the series must be stationary. First we check 
the variables in raw form mean at the level, if all the variables are not stationary at the level then they are needed to be checked on difference. There are number of tests to check the stationarity of the variable, but after going through the literature three test are most commonly used, (ADF) test Dickey and Fuller (1979), (PP) test Phillips and Perron (1988), are employed in this study to identify the stationarity and to define the order of the integration of all the included variables in the model. If the selected series is stationary in the same order then the Cointegration test will be utilized to identify the long run interrelationship within the proposed variables. The equation of the $\mathrm{ADF}$ test is as following,

$$
\Delta P_{t}=\alpha_{\circ}+\beta P_{t-1}+\sum_{i=1}^{p} \gamma_{t} \Delta P_{t-i}+\varepsilon_{t}
$$

The above Eq. $3 \alpha$ is denoted as constant, $\beta$ represents coefficient, $\mathrm{P}$ is the variable, t denoted time trend, $\Delta$ represents the first difference, $\varepsilon_{t}$ represents the random error. The unit root is tested for the coefficient of $P_{t-1}$, if the coefficient is found different from zero $(\beta \neq 0)$, after testing the unit root, the null hypothesis, the series has unit root, to be rejected, the alternative hypothesis would be accepted which is the P doesn't have the unit root.

\subsection{Panel Cointegration Test}

The Cointegration test is conducted to inspects the presence of the long run interrelationship within the proposed variables Ghali (1998), for this purpose we employ in this paper the Johansen Cointegration test Johansen (1988), to identify the long run interrelationship amongst the proposed variables. The starting point of Johansen Cointegration method is in the VAR model is the order of p specified by:

$$
y_{t}=\mu+A_{1} y_{t-1}+A_{2} y_{t-2} \ldots \ldots \ldots \ldots \ldots \ldots+A_{p} y_{t-p}+\varepsilon_{t}
$$

Where $\mathrm{y}$ is denoted as the vector of variables which are stationary in the same order one I(1), and here $\varepsilon_{t}$ is denoted as the vector of innovation. This VAR model is written as,

$$
\Delta y_{t}=\mu+\Pi y_{t-1}+\sum_{i=1}^{p-1} \Gamma_{i} \Delta y_{t-i}+\varepsilon_{t}
$$

There are two types of tests proposed by Johansen the trace test and the maximum eigenvalue test, which are shown in the Eq. 6 and 7 respectively,

$$
\begin{gathered}
\lambda_{\text {trace }}=-T \sum_{i=r+1}^{n} \log \left(1-\lambda_{i}\right) \\
\lambda_{\text {max }}=-T \log \left(1-\lambda_{i+1}\right)
\end{gathered}
$$

Where $\mathrm{T}$ is the specimen size, the null hypothesis of trace test is the $\mathrm{r}$ cointegration vectors and the alternative hypothesis is the $n$ cointegration vectors. On the other hand in the maximum eigenvalue test, the hypothesis is $r$ cointegration vectors and the alternative hypothesis is the $\mathrm{r}+1$ cointegrating vectors.

\subsection{Vector Error Correction Model (VECM)}

When all variables are cointegrated then the VECM is an appropriate model to apply. This model was introduced by (Sims, 1980). There is nothing anything in the model which specify the causality direction within the variables in the series, therefore the Granger causality based on the VECM Engle and Granger (1987) is the suitable method to examine the short run and long run interrelationship among the variables based on the following equations, We have 6 Variables and all variables have their own equation as following,

$$
\begin{gathered}
\Delta G D P_{i t}=\alpha_{1}+\sum_{l=1}^{p} \alpha_{11 i l} \Delta G D P_{i t-l}+\sum_{l=1}^{p} \alpha_{12 i l} \Delta F D I_{i t-l}+ \\
\sum_{l=1}^{p} \alpha_{13 i l} \Delta G C F_{i t-l}+\sum_{l=1}^{p} \alpha_{14 i l}+\sum_{l=1}^{p} \alpha_{15 i l} \Delta T O_{i t-l}+\sum_{l=1}^{p} \alpha_{16 i l} \Delta L_{i t-l}+\lambda_{1 t} E C T_{1 i t-1}+\mu_{1 i t} \\
\Delta F D I_{i t}=\alpha_{2}+\sum_{l=1}^{p} \alpha_{21 i l} \Delta G D P_{i t-l}+\sum_{l=1}^{p} \alpha_{22 i l} \Delta F D I_{i t-l}+\sum_{l=1}^{p} \alpha_{23 i l} \Delta G C F_{i t-l}+ \\
\sum_{l=1}^{p} \alpha_{24 i l} \Delta G C_{i t-l}+\sum_{l=1}^{p} \alpha_{25 i l} \Delta T O_{i t-l}+\sum_{l=1}^{p} \alpha_{26 i l} \Delta L_{i t-l}+\lambda_{2 t} E C T_{2 i t-1}+\mu_{2 i t}
\end{gathered}
$$

Where $\Delta$ represents the first difference, $l$ is denoted as the optimal lag length on the bases of the Schwarz Bayesian Criterion (Schwarz, 1978). $\mu_{i t}$ Indicates the residual terms and normally distributed. ECT $T_{i t-1}$ Represents the error correction term also established for the long run interrelationship within the proposed variables, and also shows the speed of adjustment from the short run to the direction of long run equilibrium in the series. The VECM is suitable to differentiate the short run and long run causal interrelationship.

\section{Empirical Results and Discussion}

This section shows the empirical results of stationarity then the cointegration test and in the end the VECM approach. The outcomes of stationarity tests are shown in Table 2, which show that the two tests Augmented Dickey-Fuller (ADF) test and Phillips \& Perron (PP) test are used. 
Table 2. Unit Root test

\begin{tabular}{cccccc}
\hline & \multicolumn{2}{c}{ At level } & & \multicolumn{2}{c}{ At First Difference } \\
\cline { 2 - 5 } Variables & ADF & PP & & ADF & PP \\
\cline { 2 - 5 } & Statistics & Statistics & Variables & 30.5878 & 49.5544 \\
LNGDP & 0.5519 & 0.5085 & \multirow{2}{*}{ D(LNGDP) } & $(0.0002)$ & $(0.0000)$ \\
& $(0.9998)$ & $(0.9999)$ & & 56.3069 & 160.996 \\
LNFDI & 20.0419 & 17.2760 & D(LNFDI) & $(0.0000)$ & $(0.0000)$ \\
& $(0.0102)$ & $(0.0274)$ & & 28.9085 & 43.3765 \\
LNGC & 15.4892 & 19.1539 & D(LNGC) & $(0.0003)$ & $(0.0000)$ \\
& $(0.0503)$ & $(0.0141)$ & & 23.2807 & 34.2710 \\
LNGCF & 6.6776 & 6.7452 & D(LNGCF) & $(0.0030)$ & $(0.0000)$ \\
& $(0.5644)$ & $(0.5644)$ & & 20.5171 & 35.0803 \\
LNL & 19.4270 & 9.0584 & D(LNL) & $(0.0085)$ & $(0.0000)$ \\
& $(0.0127)$ & $(0.3374)$ & & 32.9197 & 72.4989 \\
LNTO & 4.5575 & 7.6658 & D(LNTO) & $(0.0001)$ & $(0.0000)$ \\
\hline
\end{tabular}

The results reveal that all the variables have unit root at level $\mathrm{I}(0)$ except $\operatorname{lnGC}$ and $\operatorname{lnFDI}$ which are stationary at level. To avoid spurious regression the first difference is taken to make the data stationary. After taking the first difference all the variables become stationary and the null hypothesis $\mathrm{H}_{0}$ the series has unit root has been rejected. All the variables, don't have unit root or the variables are stationary in order I(1). Now the Johansen cointegration is a suitable method to test whether the variables are cointegrated or not.

Before applying the cointegration test the first thing is to identify the optimal lag criteria, after analyzing in this paper we applied SIC lag structure which is suitable criteria for the VEC method. The maximum value of the SIC is chosen for the number of lags. Cointegration test results are shown in the Table 3, which show that the value of trace test and maximum eigen- value tests are found significant. The null hypothesis, there is no co-integration, is rejected in both test and the alternative hypothesis is accepted in the model. The results show the presence of long-run interrelationship within the proposed variables of the series.

Table 3. Panel Cointegration test results

\begin{tabular}{cccccc}
\hline $\mathrm{H}_{0}$ & $\mathrm{H}_{1}$ & $\begin{array}{c}\text { Fisher Stat.* } \\
\text { (from trace test) }\end{array}$ & Prob. & $\begin{array}{c}\text { Fisher Stat.* } \\
\text { (from max-eigen test) }\end{array}$ & Prob. \\
\hline $\mathrm{r}=0$ & $\mathrm{r} \geq 1$ & 120.8 & 0.0000 & 45.28 & 0.0000 \\
$\mathrm{r} \leq 1$ & $\mathrm{r} \geq 2$ & 86.35 & 0.0000 & 40.65 & 0.0000 \\
$\mathrm{r} \leq 2$ & $\mathrm{r} \geq 3$ & 55.22 & 0.0000 & 30.58 & 0.0002 \\
$\mathrm{r} \leq 3$ & $\mathrm{r} \geq 4$ & 32.89 & 0.0001 & 23.45 & 0.0028 \\
$\mathrm{r} \leq 4$ & $\mathrm{r} \geq 5$ & 18.41 & 0.0183 & 9.359 & 0.3130 \\
$\mathrm{r} \leq 5$ & $\mathrm{r} \geq 6$ & 27.47 & 0.0006 & 27.47 & 0.0006 \\
\hline
\end{tabular}

* Probabilities are computed using asymptotic Chi-square distribution.

Null hypothesis: there is no cointegration.

The trend of causality can't be defined by the Johansen cointegration test however for this purpose the Granger causality test is applied which is based on the VECM. Our study focuses on the causal effect of FDI on the growth of Asian developing countries. The results of VECM are given in Table 4, the results are divided into two parts, the first part in long run and the second part is short run. The long-run results are shown under the ECTt-1 coefficient based on the t-statistics. The short-run results are shown under the VEC Granger causality test. 
Table 4. VECM Granger causality analyses

\begin{tabular}{|c|c|c|c|c|c|c|c|}
\hline \multirow{3}{*}{$\begin{array}{c}\text { Dependent } \\
\text { Variables }\end{array}$} & \multicolumn{7}{|c|}{ Type of Granger causality } \\
\hline & \multicolumn{6}{|c|}{ Short run } & \multirow{2}{*}{$\begin{array}{c}\text { Long run } \\
E C T_{t-1}\end{array}$} \\
\hline & $\Delta \ln G D P_{t-1}$ & $\Delta \ln F D I_{t-1}$ & $\Delta \ln G C F_{t-1}$ & $\Delta \ln G C_{t-1}$ & $\Delta \operatorname{lnTO} O_{t-1}$ & $\Delta \ln L_{t-1}$ & \\
\hline$\Delta \ln G D P_{t-1}$ & - & $\begin{array}{c}1.9818 \\
(0.3712)\end{array}$ & $\begin{array}{c}0.5433 \\
(0.7621)\end{array}$ & $\begin{array}{c}5.4470 \\
(0.0656)\end{array}$ & $\begin{array}{c}3.3386 \\
(0.1884)\end{array}$ & $\begin{array}{l}11.7654 \\
(0.0028)\end{array}$ & $\begin{array}{l}-0.0032 \\
(0.9069)\end{array}$ \\
\hline$\Delta \operatorname{lnFDI} I_{t-1}$ & $\begin{array}{c}0.9777 \\
(0.6133)\end{array}$ & - & $\begin{array}{c}0.0255 \\
(0.9873)\end{array}$ & $\begin{array}{c}3.2285 \\
(0.1990)\end{array}$ & $\begin{array}{c}1.3492 \\
(0.5093)\end{array}$ & $\begin{array}{c}5.0666 \\
(0.0794)\end{array}$ & $\begin{array}{l}0.9415 \\
(0.000)\end{array}$ \\
\hline$\Delta \ln G C F_{t-1}$ & $\begin{array}{l}16.8736 \\
(0.0002)\end{array}$ & $\begin{array}{c}0.2449 \\
(0.8847)\end{array}$ & - & $\begin{array}{c}4.8025 \\
(0.0906)\end{array}$ & $\begin{array}{c}4.5304 \\
(0.1038)\end{array}$ & $\begin{array}{c}0.5523 \\
(0.7587)\end{array}$ & $\begin{array}{c}0.0020 \\
(0.8962)\end{array}$ \\
\hline$\Delta \ln G C_{t-1}$ & $\begin{array}{c}0.7183 \\
(0.6983)\end{array}$ & $\begin{array}{c}0.2474 \\
(0.8836)\end{array}$ & $\begin{array}{c}1.0234 \\
(0.5994)\end{array}$ & - & $\begin{array}{c}3.0211 \\
(0.2208)\end{array}$ & $\begin{array}{c}5.8323 \\
(0.0541)\end{array}$ & $\begin{array}{l}-0.0009 \\
(0.9393)\end{array}$ \\
\hline$\Delta \operatorname{lnTO} O_{t-1}$ & $\begin{array}{l}0.0719 \\
(0.788)\end{array}$ & $\begin{array}{l}0.8513 \\
(0.356)\end{array}$ & $\begin{array}{l}0.0023 \\
(0.961)\end{array}$ & $\begin{array}{l}6.5820 \\
(0.010)\end{array}$ & - & $\begin{array}{l}0.1370 \\
(0.711)\end{array}$ & $\begin{array}{c}0.0279 \\
(0.2187)\end{array}$ \\
\hline$\Delta \ln L_{t-1}$ & $\begin{array}{c}0.0251 \\
(0.0067)\end{array}$ & $\begin{array}{c}2.7752 \\
(0.2497)\end{array}$ & $\begin{array}{c}2.3505 \\
(0.3087)\end{array}$ & $\begin{array}{c}2.0844 \\
(0.3527)\end{array}$ & $\begin{array}{c}7.0714 \\
(0.0291)\end{array}$ & - & $\begin{array}{l}-0.0016 \\
(0.2166)\end{array}$ \\
\hline
\end{tabular}

In Table 4 Granger causality based on the VECM is applied to know about the direction not only within GDP and FDI but also between gross capital formations (GCF), Government consumption (GC), trade openness (TO) and Labor. The results would help the policy makers in making policy to run the economy in the long run. The results show that in the long run when GDP is utilized as dependent variable, the coefficient of $\mathrm{ECT}_{\mathrm{t}-1}$ is negative and statistically in- significant, the negative sign of error correction term coefficient show that there is a positive interrelationship but there is no long-run interrelationship running from FDI, GC, GCF, TO, and L to GDP. On the other hand when FDI is used as the dependent variable, the results reveal that the coefficient of $\mathrm{ECT}_{\mathrm{t}-1}$ is positive and statistically significant, meaning that is a long run interrelationship running from GDP, GC, GCF, TO and L to FDI.

In short run results show that there is a bidirectional interrelationship within GDP and labor (GDP↔L). A unilateral interrelationship between government consumption and GDP (GC $\rightarrow$ GDP), there is another unilateral interrelationship running from GDP to gross capital formation ( $\mathrm{GDP} \rightarrow \mathrm{GCF}$ ), another is running from labor to FDI $(\mathrm{L} \rightarrow \mathrm{FDI})$, other unidirectional is running from trade openness to labor $(\mathrm{TO} \rightarrow \mathrm{L})$, other is from government consumption to trade openness ( $\mathrm{GC} \rightarrow \mathrm{TO}$ ), and the last one unidirectional interrelationship is running from labor to government consumption ( $\mathrm{L} \rightarrow \mathrm{GC}$ ). The results show no evidences of interrelationship from FDI to GDP and vice versa in the short run.

\section{Conclusion}

The study in hand inspected the causal influence of FDI on the economic growth of selected Asian developing countries, the sample countries are Bangladesh, India, Indonesia and Malaysia over the period of 1990 to 2014. For estimation we first used the panel unit root test to check the stationarity of the variables then applied the cointegration test to check whether the variables are cointegrated or not in the end we applied the VECM approach which is based on the Granger causality to check the direction of the proposed variables.

After going through the empirical and theoretical literature on the causal link within FDI and economic growth we found that many studies proved that the FDI and economic growth has positive impact and on the other hand some other studies proved that there is a negative impact within FDI and economic growth. In this study we also tried to find out the interrelationship between these two variables and some other important variables. We found that in the short run there is neither a unidirectional nor bidirectional interrelationship between FDI and economic growth. On the other hand in the long run FDI and other proposed variables of this study have positive impact on GDP but it is not significant. Moreover GDP and other proposed variables of this study have negative impact and it is significant.

However, by viewing the results of this study the policymakers can implement some policies. The policy makers of these countries can emphasis and make the policies which are more attractive and applicable for the enhancement of FDI in their countries. They should focus on their labor to make them skillful, and they should adopt the new ways of trade to enhance the capacity of their exports. They should not forget the expansion of gross capital formation. 


\section{References}

Acharyya, J. (2009). FDI, Growth And The Environment: Evidence From India On $\mathrm{CO}_{2}$ Emission During The Last Two Decades. Journal of Economic Development. https://doi.org/10.1029/2006GL025923

Akinlo, A. E. (2004). Foreign direct investment and growth in Nigeria. An empirical investigation. Journal of Policy Modeling, 26(5), 627-639. https://doi.org/10.1016/j.jpolmod.2004.04.011

Alshehry, A. S. (2015). Foreign Direct Investments and Economic Growth in Saudi Arabia: A Cointegration Analysis. Developing Country Studies, 3(10), 66-75. https://doi.org/10.1.1.829.9131\&rep=rep1\&type=pdf

Asheghian, P. (2004). Determinants of Economic Growth in the United States: The Role of Foreign Direct Investment. International Trade Journal. https://doi.org/10.1080/08853900490277350

Ayanwale, A. B. (2007). FDI and Economic Growth: Evidence From Nigeria. African Economic Research Consortium.

Retrieved

from https://opendocs.ids.ac.uk/opendocs/bitstream/handle/123456789/2677/RP165.pdf?sequence=1

Balasubramanyam, V. N., Salisu, M., \& Sapsford, D. (1996). Foreign direct investment and growth in EP and IS countries. Economic Journal. https://doi.org/10.2307/2234933

Basu, P., \& Guariglia, A. (2007). Foreign Direct Investment, inequality, and growth. Journal of Macroeconomics, 29(4), 824-839. https://doi.org/10.1016/j.jmacro.2006.02.004

Basu, P., Chakraborty, C., \& Reagle, D. (2003). Liberalization, FDI, and growth in developing countries: A panel cointegration approach. Economic Inquiry, 41(3), 510-516. https://doi.org/10.1093/ei/cbg024

Belloumi, M. (2014). The relationship between trade, FDI and economic growth in Tunisia: An application of the autoregressive distributed lag model. Economic Systems, 38(2), 269-287. https://doi.org/10.1016/j.ecosys.2013.09.002

Bhatt, P. (2014). Foreign direct investment in ASEAN. Economic Review of Galicia, 23(4), 109-146. Retrieved from

http://scholar.google.com.my/scholar?hl=en\&q=malaysian+economic\&btnG=\&as_sdt=1,5\&as_sdtp=\#13

Borensztein, E., De Gregorio, J., \& J. W. L. (1998). How does foreign direct investment affect economic growth. Journal of International Economics, 45(1), 115-135. https://doi.org/10.1016/S0022-1996(97)00033-0

Brooks, D. H., Roland-Holst, D., \& Zhai, F. (2008). Behavioral and empirical perspectives on FDI: International capital allocation across Asia. Journal of Asian Economics, 19(1), 40-52. https://doi.org/10.1016/j.asieco.2007.10.004

Carkovic, M., \& Levine, R. E. (2002). Does Foreign Direct Investment Accelerate Economic Growth? SSRN Electronic Journal. https://doi.org/10.2139/ssrn.314924

Chakraborty, C., \& Basu, P. (2002). Foreign direct investment and growth in India: A cointegration approach. Applied Economics, 34(9), 1061-1073. https://doi.org/10.1080/00036840110074079

De Mello, \& R, J. L. (1999). Foreign direct investment-led growth: Evidence from time series and panel data. Oxford Economic Papers, 5l(FEBRUARY 1999), 133-151. https://doi.org/10.1093/oep/51.1.133

Dickey, D. A., \& Fuller, W. A. (1979). Distribution of the Estimators for Autoregressive Time series with a Unit Root. Journal of the American Statistical Association, 74(366), 427-431. https://doi.org/10.2307/2286348

Duasa, J. (2007). Malaysian Foreign Direct Investment and Growth: Does Stability Matter? Journal of Economic Cooperation, 28(2), 83-98. $\quad$ Retrieved from https://pdfs.semanticscholar.org/4690/7768ba5819ccc911c3efedd33856cc690451.pdf

Emirmahmutoglu, F., \& Kose, N. (2011). Testing for Granger causality in heterogeneous mixed panels. Economic Modelling, 28(3), 870-876. https://doi.org/10.1016/j.econmod.2010.10.018

Engle, R. F., \& Granger, C. W. J. (1987). Co-integration and Error Correction: Representation, Estimation, and Testing. Econometrica, 55(2), 251-76. https://doi.org/http://dx.doi.org/10.2307/1913236

Fedderke, J. W., \& Romm, A. T. (2006). Growth impact and determinants of foreign direct investment into South Africa, 1956-2003. Economic Modelling, 23(5), 738-760. https://doi.org/10.1016/j.econmod.2005.10.005

Figlio, D. (2000). The Effects of Foreign Direct Investment on Local Communities. Journal of Urban Economics, 48, 338-363. https://doi.org/doi:10.1006?juec.2000.2170

Fosfuri, A., Motta, M., \& Rønde, T. (2001). Foreign direct investment and spillovers through workers' mobility. 
Journal of International Economics, 53(1), 205-222. https://doi.org/10.1016/S0022-1996(00)00069-6

Fowowe, B. (2011). The Finance-Growth Nexus in Sub-Saharan Africa: Panel Cointegration and Causality Tests. Journal of International Development, 220-239. https://doi.org/10.1002/jid.1660

Frimpong, J. M., \& Oteng-Abayie, E. F. (2006). inflows and economic growth in Ghana. African Finance Journal, (351). Retrieved from https://mpra.ub.uni-muenchen.de/351/1/MPRA_paper_351.pdf

Ghali, K. H. (1998). Public investment and private capital formation in a vector error-correction model of growth. Applied Economics, 30(6), 837-844. https://doi.org/10.1080/000368498325543

Ghirmay, T., Grabowski, R., \& Sharma, S. C. (2001). Exports, investment, efficiency and economic growth in LDC: an empirical investigation. Applied Economics, 33, 689-700. https://doi.org/10.1080/00036840122027

Glass, A. J., \& Saggi, K. (2002). Multinational Firms and Technology Transfer. Scandinavian Journal of Economics, 104(4), 495-513. https://doi.org/10.1111/1467-9442.00298

Günther, J. (2002). FDI as a multiplier of modern technology in Hungarian industry. Intereconomics, 37(5), 263-269. https://doi.org/10.1007/BF02928885

Herzer, D., Klasen, S., \& Nowak-Lehmann D., F. (2008). In search of FDI-led growth in developing countries: The way forward. Economic Modelling, 25(5), 793-810. https://doi.org/10.1016/j.econmod.2007.11.005

Hsiao, F. S. T., \& Hsiao, M. C. W. (2006). FDI, exports, and GDP in East and Southeast Asia-Panel data versus time-series causality analyses. Journal of Asian Economics, 17(6), 1082-1106. https://doi.org/10.1016/j.asieco.2006.09.011

Johansen, S. (1988). Statistical analysis of cointegration vectors. Journal of Economic Dynamics and Control, 12(2-3), 231-254. https://doi.org/10.1016/0165-1889(88)90041-3

Jr., L. R. D. M. (1997). Foreign direct investment in developing countries and growth: A selective survey. Journal of Development Studies, 34(1), 1-34. https://doi.org/10.1080/00220389708422501

Kakar, Z., \& Khilji, B. (2011). Impact of FDI and trade openness on economic growth: A comparative study of Pakistan and Malaysia. Theoretical and Applied Economics, XVIII(11), 53-58. Retrieved from http://store.ectap.ro/articole/661.pdf

Kalai, M., \& Zghidi, N. (2017). Foreign Direct Investment, Trade, and Economic Growth in MENA Countries: Empirical Analysis Using ARDL Bounds Testing Approach. Journal of the Knowledge Economy. https://doi.org/10.1007/s13132-017-0460-6

Kaufmann, L. (1997). A model of spillovers through labor recruitment. International Economic Journal, 11(3), 13-33.

Kholdy, S. (1995). Causality between foreign investment and spillover efficiency. Applied Economics, 27(8), 745-749. https://doi.org/10.1080/00036849500000064

Lian, L., \& Ma, H. (2013). FDI and Economic Growth in Western Region of China and Dynamic Mechanism: Based on Time-Series Data from 1986 to 2010. International Business Research, 6(4), 180-187. https://doi.org/10.5539/ibr.v6n4p180

Lipsey, R. E. (2000). Inward FDI and economic growth in developing countries. Transnational Corporations, 9(1), 67-96.

Lipsey, R. E., Sjöholm, F., \& Sun, J. (2013). Foreign Ownership and Employment Growth in a Developing $\begin{array}{lllll}\text { Country. Journal of Development } & \text { Studies, } & 49(8), & 1133-1147 .\end{array}$ https://doi.org/10.1080/00220388.2013.794264

Ludosean, B. M. (2012). A VAR analysis of the connection between FDI and economic grwoth in Romania. Theoretical and Applied Economics, 10, 115-130. Retrieved from https://core.ac.uk/download/pdf/25727499.pdf

Mencinger, J. (2003). Does Foreign Direct Investment Always Enhance Economic Growth? Kyklos, 56(4), 491-508. https://doi.org/10.1046/j.0023-5962.2003.00235.x

Moudatsou, A., \& Kyrkilis, D. (2011). FDI and economic growth: causality for the EU and ASEAN. Journal of Economic Integration, 26(3), 554-577. https://doi.org/10.2753/JEI0021-3624440301

Mutafoglu, T. H. (2012). Foreign Direct Investment, Pollution, and Economic Growth: Evidence from Turkey. 
Journal of Developing Societies, 28(3), 281-297. https://doi.org/10.1177/0169796X12453780

Pahlavani, M., Wilson, E., \& Worthingt, A. C. (2005). Trade-GDP Nexus in Iran: An Application of the Autoregressive Distributed Lag (ARDL) Model. American Journal of Applied Sciences, 2(7), 1158-1165. https://doi.org/10.3844/ajassp.2005.1158.1165

Pegkas, P. (2015). The impact of FDI on economic growth in Eurozone countries. The Journal of Economic Asymmetries, 12(2), 124-132. https://doi.org/10.1016/j.jeca.2015.05.001

Phillips, P., \& Perron, P. (1988). Testing for a Unit Root in Time Series Regressions. Biometrika, 75(2), 335-346. https://doi.org/10.2307/2336182

Rahman, M. (2007). Contributions of Exports, FDI and Expatriates' Remittances to Real GDP of Bangladesh, India, Pakistan and Sri Lanka. Southwestern Economic Review, 36(1), 141-153. Retrieved from http://www.ser.tcu.edu/2009/SER2009 Rahman 141-154.pdf

Reichert, Nair, U., \& Weinhold, D. (2001). Causality tests for cross-country panels: A new look at FDI and economic growth in developing countries. Oxford Bulletin of Economics and Statistics, 63(2), 153-171.

Schwarz, G. (1978). Estimation the Dimension of a Model. Annals of Statistics, 6(2), 461-464. Retrieved from https://projecteuclid.org/download/pdf_1/euclid.aos/1176344136

Sims, C. A. (1980). Macroeconomics and Reality. The Econometric Society, 48(1), 1-48. Retrieved from http://www.jstor.org/stable/1912017

Sothan, S. (2017). Causality between foreign direct investment and economic growth for Cambodia. Cogent Economics \& Finance, 5(1), 1277860. https://doi.org/10.1080/23322039.2016.1277860

Srinivasan, P., Kalaivani, M., \& Ibrahim, P. (2011). An empirical investigation of foreign direct investment and economic growth in SAARC nations. Journal of Asia Business Studies, 5(2), 232-248. https://doi.org/10.1108/15587891111152366

Tan, B. W., \& Tang, C. F. (2016). Examining the Causal Linkages among Domestic Investment, FDI, Trade, Interest Rate and Economic Growth in ASEAN-5 Countries. International Journal of Economics and Financial Issues, 6(1), 214-220.

Tang, S., Selvanathan, E. A., \& Selvanathan, S. (2008). Foreign direct investment, domestic investment and economic growth in China: A time series analysis. World Economy, 31(10), 1292-1309. https://doi.org/10.1111/j.1467-9701.2008.01129.x

Toda, H. y, \& Phillips, P. C. . (1993). Vector Autoregressions and Causality. Econometrica, 61(6), 1367-1393. Retrieved from http://www.jstor.org/stable/2951647\%0AEconometrica,

Tomohara, A., \& Takii, S. (2011). Does globalization benefit developing countries? Effects of FDI on local wages. Journal of Policy Modeling, 33(3), 511-521. https://doi.org/10.1016/j.jpolmod.2010.12.010

Umoh, O., Jacob, A., \& Chuku, C. (2012). Foreign Direct Investment and Economic Growth in Nigeria: An Analysis of the Endogenous Effects. Current Research Journal of Economic Theory, 4(3), 53-66.

Vogiatzoglou, K., \& Nguyen, P. N. T. (2016). Economic Openness and Economic Growth: A Cointegration Analysis for Asean-5 Countries. European Journal of Applied Economics, 13(2), 10-20. https://doi.org/10.5937/ejae13-11311

Waldkirch, A., Nunnenkamp, P., \& Bremont, J. E. A. (2009). Employment effects of FDI in Mexico's non-maquiladora Manufacturing. Journal of Development Studies, 45(7), 1165-1183. https://doi.org/10.1080/00220380902952340

Wang, J. Y., \& Blomström, M. (1992). Foreign investment and technology transfer. European Economic Review, 36(1), 137-155. https://doi.org/10.1016/0014-2921(92)90021-N

Wang, Y. (2010). FDI and productivity growth: the role of inter-industry linkages. Canadian Journal of Economics/Revue Canadienne D'économique, 43(4), 1243-1272. https://doi.org/10.1111/j.1540-5982.2010.01613.x

WDI. (2017). The World Bank. Retrieved from http://databank.worldbank.org/data/home.aspx

Xu, B. (2000). Multinational enterprises, technology diffusion, and host country productivity growth. Journal of Development Economics, 62, 477-493. Retrieved from http://www.elsevier.comrlocatereconbase

Zhang, K. H. (2001). Does Foreign Direct Investment Promote Economic Growth? Evidence from East Asia and 


\section{Latin America. Contemporary $\quad$ Economic Policy, $175-185$.} https://doi.org/10.1111/j.1465-7287.2001.tb00059.x

Zhang, K. H., \& Song, S. (2000). Promoting exports: The role of inward FDI in China. China Economic Review, 11(4), 385-396. https://doi.org/10.1016/S1043-951X(01)00033-5

Zhao, Z., \& Zhang, K. H. (2010). FDI and industrial productivity in China: Evidence from panel data in 2001-06. Review of Development Economics, 14(3), 656-665. https://doi.org/10.1111/j.1467-9361.2010.00580.x

Zhou, D., Li, S., \& Tse, D. K. (2002). The impact of FDI on the productivity of domestic firms: The use of China. International Business Review, 11(4), 465-484. https://doi.org/10.1016/S0969-5931(02)00020-3

\section{Copyrights}

Copyright for this article is retained by the author(s), with first publication rights granted to the journal.

This is an open-access article distributed under the terms and conditions of the Creative Commons Attribution license (http://creativecommons.org/licenses/by/4.0/). 